\title{
ANALISIS LOAN TO DEPOSIT RATIO DAN NON PERFOMING LOAN PADA PT. BANK PERKREDITAN RAKYAT JORONG KAMPUNG TANGAH PARIAMAN
}

\author{
Alifa Hayati, Afriyeni \\ Akademi Keuangan Dan Perbankan "Pembangunan" Padang \\ Alifa03hayati@gmail.com
}

\begin{abstract}
This study aims to analyze and add insight about credit by using a Loan to Deposit Ratio (LDR) and Non Performing Loans (NPL) at PT. BPR Jorong Kampung Tangah Pariaman to find out the efficiency and effectiveness of third party funds and bad loans owned by this bank. The data used is taken from secondary data from the financial data documentation of PT. BPR Jorong, the village of Tangah Pariaman. The results showed quite good because third party funds declined slightly while bad loans were balanced
\end{abstract}

Keyword: Bank, Loan To Deposit Ratio (LDR), Non Perfoming Loan (NPL)

\section{PENDAHULUAN}

Dalam era globalisasi perekonomian saat ini tidak terlepas dari dunia perbankan, karena salah satunya sudah menjadi dasar yang membantu perekonomian di zaman yang semakin canggih seperti sekarang ini. Untuk meningkatkan pertumbuhan ekonomi orang banyak serta menciptakan ekonomi yang stabil melalui bank-bank yang ada di Indonesia. Bank merupakan alah satu lembaga keuangan yang memiliki peranan penting dalam menghimpun dana dan meminjamkan dana kepada masyarakat dengan syarat yang telah ditentukan oleh bank. Bank umum di Indonesia baik bank milik pemerintah, asing, campuran maupun swasta pada saat ini belum dapat menjangkau seluruh lapisan masyarakat terutama dalam hal pemberian kredit. Bank dapat dikatakan sebagai pendorong utama roda perekonomian karena sebagai alternative.sumber modal guna menggunakan sektoriil, mendanai negara dan juga membiyai kebutuhan masyarakat pada umumnya.

\section{LANDASAN TEORI \\ Pengertian Bank}

Menurut(Nomor 10 tahun 1998 perubahan atas undang undang nomor 7 tahun 1992, 1998) Bank merupakan suatu badan usaha yang menghimpun dana dari masyarakat kemudian menyalurkannya lagi kepada masyarakat dalam bentuk tabungan deposito dan giro. Dalam era globalisasi, perbankan dan minat yang banyak dari masyarakat, banyak bank yang mulai bermunculan, salah satunya PT. Bank Perkreditan Rakyat Jorong Kampung Tangah Pariaman yang merupakan 
salah satu bank yang sangat berperan penting dalam pertumbuhan ekonomi di kalangan masyarakat pedesaan di indonesia.

\section{Fungsi Bank}

Fungsi bank secara umum adalah menghimpun dana dari masyarakat luas (funding) dan menyalurkan dalam bentuk pinjaman atau kredit (lending) untuk berbagai tujuan.Menurut (Santoso, 2006) adalah Sebagai Berikut :

a. Agent Of Trust

Kepercayaan yang baik guna memperlancar kegiatan bank yaitu menghimpun dan menyalurkan.

b. Agent Of Development

Pembangunan perokonomian masyarakat juga menjadi fungsi bank dalam mendukung pemerintah.

c. Agent Of Service.

Memberikan jasa-jasa yang bersangkutan dengan keuangan yang ada dalam produk bank tersebut sperti kliring dan lain sebagainya

\section{Jenis Jenis bank}

a. Dilihat dari Segi Fungsi, dibagi menjadi:

1) Bank Umum adalah bank yang menjalankan kegiatan secara konvensional berdasarkan prinsip syariah kepada masyarakat umum yang dalam kegiatannya memberikan jasa dalam lalu lintas pembayaran.

2) Bank Perkreditan Rakyat (BPR), adalah Bank yang melaksanakan kegiatan usaha secara konvensional atau berdasarkan prinsip syariah yang dalam kegiatannya tidak memberikan jasa dalam lalu lintas pembayaran terutama pada masyarakat menengah kebawah.

a. Dilihat dari Segi Kepemilikan, dibagi menjadi:

1) Bank Milik Pemerintah, yaitu suatu lembaga keuangan yang dimiliki oleh pemerintah pusat yang modal dan pendiriannya dari pemerintah pula. Kemudian keuntungan yang didapatkan oleh badan tersebut adalah milik pemerintah juga. Sedangkan Bank Milik Pemerintah Daerah, yaitu lembaga keuangan yang dimiliki oleh pemerintah daerah yang modal dan pendiriannya dari pemerintah pula. Kemudian keuntungan yang didapatkan oleh badan tersebut adalah juga milik pemerintah.

2) Bank Milik Swasta Nasional, merupakan bank yang kegaiatn dan opersionalnya ditanggung oleh swasta bukan pemerintah.

3) Bank Milik Asing, merupakan lembaga cabang dari bank yang ada di luar negeri, baik milik swasta asing maupun pemerintah asing yang ada di Luar Negeri baik milik swasta asing atau pemerintah asing yang keuntungannya dimiliki oleh bank milik asing.

4) Bank Milik Campuran, merupakan bank yang kepemilikan sahamnya dimiliki oleh pihak asing dan pihak swasta nasional 


\section{Sumber Dana Bank}

apabila lembaga tersebut mendirikan atau mendapatkan laba maka hal tersebut akan dibagi sesuai dengan hak masing.

Menurut pendapat (Kasmir, 2014) jenis sumber dana bank dibagi menjadi :

a. Dana yang bersumber dari bank itu sendiri

Sejumlah dana dari pemegang saham yang diberikan kepada bank itu sendiri.

b. Cadangan-cadangan

Sebagaian dari laba yang disisihkan untuk mengurangi resiko yang timbul dalam bentuk cadangan modal dan cadangan lainnya.

c. Laba yang ditahan

Keuntungan yang tidak dibagikan kepada pemegang saham atas kehendak pemegang saham untuk digunakan sebagai opersional perusahaan.

d. Dana yang berasal dari masyarakat luas

1) Kredit likuiditas dari Bank Indonesia

Bantuan dana dari Bank Indonesia untuk membiayai masyarakat yang kedalam bentuk bermacam- macam dalam kegiatan usaha masyarakat.

2) Perjanjian antar bank

Pinjaman dana yang dilakukan oleh du aba $\mathrm{k}$ atau lebih guna memenuhi kebutuhan perusahaan. Waktu call money biasanya ditentukan oleh bank biasanya waktu ini tidak lama satu jam atau satu bulan saja.

3) Surat berharga pasar uang

Kegiatajn pendanaan yang dilkukan oleh lembaga non bank kepada masyarakat yang bersumber dari instansi lin tersebut yang berbentuk sama dengan kredit yang diberikan oleh bank hanya saja kreditur nya bukan bersal dari lembaga keuanagan.

Kegiatan yang dilakukan oleh lembaga non bank yaitu pinjaman dari lembaga keuangan bukan bank dana yang bersumber dari lembaga lainnya yang tidak berbentuk pinjaman atau kredit, tetapi berbentuk surat berharga yang dapat diperjual belikan sebelum tanggal yang ditentukan oleh pihak yang bersangkutan kapan akan diselesaikan atau bisa disebut dengan dana yang bersumber dari lembaga lainnya.

1. Simpanan giro

Penyimpanan yang dilakukan oleh nasabah yang kegiatannya pencairannya hanya dapat dilkukan pada pemindah bukuan atau cek dan bilyet giro.

2. Simpanan Tabungan 
Simpanan pihak ketiga pada bank yang penarikannya hanya dapat dilakukan menurut syarat-syarat tertentu dan dapat di ambil kapan saja.

3. Simpanan deposito

Penyimpanan yang dilakukan oleh nasabah kepada bank yang penarikannya hanya dapat dilakukan pada jadwal jatuh tempo yang telah ada perjanjian yang sudah disepakati awal penyimpanan.

4. Jasa perbankan lainnya

Meliputi kiriman uang transfer, kliring, inkasa, safe deposit box, bank card, cek wisata dan lain sebagainya.

PT. Bank Perkreditan Rakyat Jorong Kampung Tangah (JKT) Pariaman adalah salah satu lembaga keungan yang memberikan fasilitas kredit terhadap masyarakat. Masyarakat dapat memanfaatkan fasilitas layanan ini untuk meminjam uang yang nantinya dapat digunakan sesuai dengan tujuan awal peminjaman. Keberadaan PT. Bank Perkreditan Rakyat Jorong Kampung Tangah (JKT) Pariaman sendiri sebagai suatu lembaga keuangan yang mempunyai fungsi memberikan pelayanan perbankan dan membantu dalam meningkatkan taraf hidup rakyat masyarakat memberikan manfaat yang besar baik dalam hal penghimpunan dana maupun penyaluran dana kepada masyarakat. Dengan adanya PT. Bank Pekreditan Rakyat Jorong Kampung Tangah (JKT) Pariaman ini diharapkan dapat memberikan manfaat yang optimal kepada masyarakat dalam rangka meningkatkan taraf hidup rakyat banyak.

Laporan Keuangan merupakan alat yang sangat penting untuk memperoleh informasi sehubungan dengan posisi keuangan dan hasil-hasil operasi yang telah dicapai oleh perusahaan itu sendiri. Menurut (Sanjaya \& Marlius, 2017), laporan keuangan adalah suatu catatan keuangan perusahaan yang berisi data kuantitatif yang menggambarkan kondisi perusahaan dalam suatu periode. Jadi, disimpulkan bahwa laporan keuangan artinya laporan yang dapat menggambarkan kondisi keuangan perusahaan kuantitatif yang dapat berguna pihak-pihak luar maupun dalam perusahaan, yang dapat dipergunakan menilai perusahaan tersebut apakah baik atau tidak dalam kegiatan manajemen kuanagannya bagi yang membutuhkan laporan keuangan tersebut.

Salah satu cara untuk memperoleh modal adalah dengan kredit. Kredit merupakan suatu fasilitas keuangan yang memungkinkan seseorang atau badan usaha untuk meminjam uang untuk membeli produk dan membayarnya kembali dalam jangka waktu yang ditentukan. menyebutkan (Herman \& Widayati, n.d.) kredit adalah penyediaan uang atau tagihan yang dapat dipersamakan dengan itu, berdasarkan persetujuan atau kesepakatan pinjam meminjam antara bank dengan pihak lain yang mewajibkan pihak peminjam untuk melunasi utangnya setelah jangka waktu tertentu 
dengan pemberian bunga. Jika seseorang menggunakan jasa kredit, maka ia akan dikenakan bunga tagihan.

Adapun penjelasan untuk analisis dengan $5 \mathrm{C}$ kredit adalah sebagai berikut :

1. Character (Kepribadian)

Suatu keyakinan bahwa, kreditur harus tau bagaimana watak dan sifat para calon nasabahnya supaya bisa bertanggung jawab dengan janji yang disepakati.

2. Capacity (Kemampuan)

Yaitu suatu kemapuan nasabah dalam membayarkan kewajibannya dilihat dari usaha atau kegiatan yang dilakukannya . karna ini menyangkut laba atau kegiatan yang berhubungan dengan kelansungan perusahaan.

3. Capital (modal)

jumlah dana atau modal sendiri yang dimiliki oleh calon nasabah. Sebab semakin bertambah modal yang dimiliki oleh nasabah untuk usaha maka semakin baik bisnis yang dilakukan oleh karena itu bank akan merasa lebih yakin dalam memberikan kredit.

4. Collateral (jaminan)

Prinsip ini perlu diperhatikan oleh nasabah atau bank krena jika debitur tidak dapat mengembalikan dana tersebut maka bank menyita jaminan yang diberikan untuk pertanggung jawaban. Sebelumnya bank perlu mencek barang yang jadi jaminan tersebut apakah masih layak untuk dijadikan jaminan atau tidak.

5. Condition of Economi

Prinsip ini dipengaruhi oleh faktor diluar dari pihak bank maupun nasabah. Karena ini menyangkut faktor alam atau faktor lainnya yang diluar kendali pihak bank dan nasabah. Artinya tidak disengaja oleh kedua belah pihak yang bersangkutan. Contohnya terjadinya kebakaran atau keabanjiran dan lain sebagainya yang menghambat lalu lintas pembayaran.

Menurut (Agustiningrum, 2011)Non Performing Loan (NPL) adalah kreditur yang tidak sanggup membayar angsurannya sesuai dengan waktu yang disepakati sehingga terjadi tunggakan yang tidak dibayarkan kepada pihak yang bersangkutan. Artinya nasabah yang tidak bisa membayarkan kewajiban dengan tepat waktu berdasarkan perjanjian kredit pada awal kesepakatan yang telah disetujui oleh kedua belah pihak baik pihak nasabah atau phak bank yang bersangkutan. Ratio ini juga mengukur tingkat kesehatan bank dalam masalah apakah kredit yang diberikn berjalan lancar atau tidak.

NPL merupakan adanya masalah kredit dalam bank, yang apabila tidak segera ditindak lanjuti, maka akan menyebabkan bank rugi dan tidak mendapatkan keuntungan atas kredit yang diberikan kepada masyarakat. Masalah ini harus segera di atasi oleh bank atau pihak debitur yang berkaitan dengan bank tersebut. Setelah kredit diberikan kepada debitur, pihak kreditur wajib melakukan survei terhadap penggunaan kredit seberapa kemampuan dan kepatuh debitur dalam memenuhi kewajibannya agar tidak terjadinya kredit macet untuk selanjutnya yang dapat merugikan perusahaan atau kreditur. Karena dapat menghambat kegiatan kredit bank 
dan terahambatnya tujuan pokok perusahaan yaitu memperoleh laba dari kegiatan yang dilakukan

Kemampuan perusahaan untuk memenuhi kewajibanya atau membayar utang jangka pendek disebut rasio likuiditas, jika suatu perusahaan tidak mampu membayar kewajiban atau utang jangka pendek maka berarti perusahaan itu tidak likuid dan sebaliknya. Rasio yang dapat mengukur kewajiban tersebut adalah rasio Loan to Deposit Ratio (LDR) (Fernos, 2008)

Liquiditas sangat diperlukan demi menjaga kelansungan perusahaan dalam memenuhi kewajiban apabila nasabah melakukan penarikan maka perusahaan bisa memanfaatkan aset dan kredit yang ada dalam perusahaan. Jika nilai ratio kredit macet dalam persahaan terlalu tinggi, artinya perbankan tidak memiliki likuiditas yang cukup untuk menutup kewajibannya terhadap nasabah (DPK). Karena jika LDR rendah maka bank tersebut tidak bisa membayar kewajibannya, apabila NPL tinggi maka bank bisa membayarkan tagihan atau kewajiban perusahaan.

Berikut adalah data perkembangan kredit yang diberikan, dana pihak ketiga dan total kredit bermasalah pada PT. Bank Perkrditan Rakyat Jorong Kampung Tangah.

\section{Tabel 1}

Kredit Yang Diberikan, Dana Pihak Ketiga dan Kredit Bermasalah PT. BPR JKT Pariaman

Tahun 2017-2019

(Ribuan Rp)

\begin{tabular}{|l|c|c|c|}
\hline \multirow{2}{*}{ Tahun } & \multicolumn{3}{|c|}{ Keterangan } \\
\cline { 2 - 4 } & Dana Pihak Ketiga & $\begin{array}{c}\text { Total kredit yang } \\
\text { diberikan }\end{array}$ & Kredit bermasalah \\
\hline 2017 & 37.436 .953 & 33.667 .703 & 721.979 \\
\hline 2018 & 39.865 .393 & 37.375 .950 & 785.593 \\
\hline 2019 & 43.741 .078 & 40.136 .634 & 1.168 .651 \\
\hline
\end{tabular}

Sumber: PT. BPR JKT Pariaman

Dari tabel 1peningkatan dari tahun 2017 sampai tahun 2019. begitu pula dengan total kredit yang diberikan mengalami peningkatan dari tahun 2017 sampai 2019 dan total kerdit bermasalah terus meningkat setiap tahunnya dari 2017 sampai 2019.

Berdasarkan uraian diatas maka tujuan penelitian ini yaitu untuk mengetahui Analisis Loan To Deposit Ratio dan Non Perfoming Loan pada PT. Bank Perkreditan Rakyat Jorong Kampung Tangah periode 2017,2018 dan 2019.

\section{METODE PENELITIAN}

Dalam pengumpulan data dan bahan untuk melakukan penelitian ini, penulis menggunakan metode dengan dua cara sebagai berikut : a. Peninjauan Langsung ke 
Objek yaitu penelitian langsung ke objek penelitian yang dipilih untuk meneliti hasil data primer. Penelitian langsung kelapangan ini akan dapat membantu penulis untuk menambahkan data yang diperlukan. Adapun cara riset lapangan ini yaitu dengan cara mewawancarai langsung pihak terkait dalam hal ini adalah perusahaan atau instansi terkait. b. Studi Keperpustakaan (Lebrary Research) yaitu Penelitian ini dilakukan ke perpustakaan berupa buku-buku ilmiah dan tulisan-tulisan yang berhubungan dengan pembahasan yang dilakukan.

\section{HASIL DAN PEMBAHASAN}

\section{Analisis Loan To Deposit Ratio (LDR)}

Loan To Deposit Ratio adalah kemapuan bank dalam memberikan atau membayarkan kembali kewajiban segera yakninya penarikan yang dilkukan nasabah dengan memanfaatkan asset dan kredit yang ada. Kewajiban tersebut berupa call money yang harus dipenuhi pada saat adanya kewajiban kliring, yang pemenuhannya dilakukan dari aktiva lancar yang dimiliki perusahaan(Triaryati, 2012).

Loan To Deposit Ratio (LDR) digunakan untuk mengukur kemampuan bank tersebut mampu membayar hutang-hutangnya dan membayar kembali, serta dapat memenuhi permintaan kredit yang diajukan. LDR adalah rasio antara seluruh jumlah kredit yang diberikan terhadap dana pihak ketiga. Besarnya jumlah kredit yang disalurkan akan menentukan keuntungan bank. Jika bank tidak mampu menyalurkan kredit sementara dana yang terhimpun banyak maka akan menyebabkan bank tersebut rugi(Agustiningrum, 2011).

Loan To Deposit Rasio (LDR) dapat dirumuskan sebagai berikut (Surat Edaran Bank Indonesia No 3/30 DPNP tanggal 14 Desember 2001):

$$
L D R=\frac{\text { Total Kredit yang Diberikan }}{\text { Dana Pihak Ketiga }+ \text { Modal }} \times 100 \%
$$

Dimana :

LDR

Total Kredit

= Loan To deposit Ratio

Total Deposit

Equity

$=$ Total kredit yang disalurkan

$=$ Total dana pihak ketiga

$=$ Modal sendiri

Berdasarkan data yang diperoleh Loan To Deposit Ratio PT. BPR JKT Pariaman periode Desember 2017 sampai Desember 2019 ditunjukan pada tabel di bawah ini : 
Table 2

Perhitungan Loan To Deposit Rasio (LDR)

PT. BPR JKT Pariaman

Periode 2017-2019

\begin{tabular}{|c|c|c|c|}
\hline Tahun & $\begin{array}{c}\text { Jumlah kredit } \\
\text { Yang diberikan } \\
\text { (juta) } \\
(\mathbf{1})\end{array}$ & $\begin{array}{c}\text { Dana pihak } \\
\text { Ketiga } \\
\text { (Juta) } \\
\text { (2) }\end{array}$ & $\begin{array}{c}\text { LDR } \\
(\mathbf{1 : 2 )} \mathbf{x} \mathbf{1 0 0 \%}\end{array}$ \\
\hline 2017 & 33.667 .703 & 37.436 .953 & 89 \\
\hline 2018 & 37.375 .950 & 39.865 .393 & 93 \\
\hline 2019 & 40.136 .634 & 43.741 .078 & 91 \\
\hline
\end{tabular}

Sumber: PT.BPR JKT Pariaman Data Diolah

Tahun 2017

$$
\begin{gathered}
L D R=\frac{\text { Total Kredit yang Diberikan }}{\text { Total Dana Pihak Ketiga }} \times 100 \% \\
\frac{\text { Rp. } 33.667 .703}{\text { Rp. } 37436953} \times 100 \% \\
=89 \%
\end{gathered}
$$

Loan To Deposit Ratio PT. BPR JKT Pariaman pada Desember tahun 2017 sebesar 89\%.Hal tersebut sesuai dengan ketentuan standar Bank Indonesia bahwa LDR kecil dari $85 \%$ dalam keadaan sehat.

Tahun 2018

$$
\begin{gathered}
\text { LDR }=\frac{\text { Total Kredit yang Diberikan }}{\text { Dana Pihak Ketiga }} \times 100 \% \\
\frac{R p .37 .375 .950}{R p .39 .865 .393} \times 100 \% \\
=93 \%
\end{gathered}
$$

Loan To Deposit Ratio pada Desember 2018 sebesar 93\%. Hal tersebut sesuai dengan ketentuan standar Bank Indonesia bahwa LDR kecil dari $85 \%$ dalam keadaan sehat.

Tahun 2019

$$
\begin{gathered}
L D R=\frac{\text { Total Kredit yang Diberikan }}{\text { Dana Pihak Ketiga }+ \text { Modal }} \times 100 \% \\
L D R=\frac{\text { Rp. } 40.136 .634}{\text { Rp. } 43.741 .075} \times 100 \% \\
=91 \%
\end{gathered}
$$

Loan To Deposit Ratiopada Desember 2019 sebesar 91\%. Hal tersebut sesuai dengan ketentuan Bank Indonesia bahwa LDR kecil dari $85 \%$ dalam keadaan sehat. 


\section{AnalisisNon Perfoming Loan (NPL)}

kredit bermasalah yaitu suatu transaksi yang tidak dilakukan oleh nasabah kepada bank yakni tidak membayarkan kredit yang telah diberikan kepada nasabah sesuai dengan waktu yang ditentukan yang pembayarannya termasuk pokok dan bunga yang disepakati.

Non Perfoming Loan (NPL) adalah debitur atau kelompok debitur yang masuk dalam golongan kurang lancar, diragukan, macet dari golongan kredit, hendaknya selalu di ingat bahwa perubahan pengolongan kredit dari kredit lancar menjadi NPL, secara berharap melalui proses penurunan kualitas kredit.

Salah satu risiko yang muncul akibat semakin kompleknya kegiatan perbankan adalah munculnya NPL yang semakin besar. Jika terjadinya masalah kredit seperti itu maka sebaiknya diselesaikan dengan segera dan cepat mengambil tindakan penyelesaian dan tindakan yang tidak merugikan perusahaan. Dengan kata lain semakin besar kredit yang bermasalah atau operasi maka semakin buruk yang akan diterima oleh bank karena besarnya dana yang tidak diterima kembali baik pokok atau nunga yang diharapkan sebagai keuntungan yang diinginkan. (Fernos, 2008).

Peraturan Bank Indonesia (PBI) menetapkan Bahwa rasio Kredit Bermasalah Non Perfoming Loan (NPL) adalah sebesr 5\%. Rumus perhitungan NPL adalah sebagai berikut:

$$
N P L=\frac{\text { Total Kredit Bermasalah }}{\text { Total Kredit }} \times 100 \%
$$

Dimana:

NPL = Non Perfoming Loan

Total Kredit $=$ total kredit yang disalurkan

Kredit bermasalah $\quad=$ Total Kredit yang bermasalah

Berdasarkan data yang penulis peroleh berikut adalah tabel perhitungan Non Perfoming Loan (NPL) PT. BPR JKT Pariman periode Desember 2017 - Desember 2019 : 
Tabel 3

Perhitungan Non Perfoming Loan (NPL)

PT. Bank Perkrditan Rakyat Jorong Kampung Tangah

Tahun 2017-2019

\begin{tabular}{|l|c|c|c|}
\hline ahun & $\begin{array}{c}\text { umlah NPL (Juta } \\
\text { Rupiah ) } \\
\text { (1) }\end{array}$ & $\begin{array}{c}\text { mlah Kredit (Juta } \\
\text { Rupiah) } \\
\text { (2) }\end{array}$ & $\begin{array}{c}\text { NPL\% } \\
\mathbf{( 1 : 2 x 1 0 0 )}\end{array}$ \\
\hline 2017 & 721.979 & 33.667 .703 & $2 \%$ \\
\hline 2018 & 785.593 & 37.375 .950 & $2 \%$ \\
\hline 2019 & 1.168 .651 & 40.136 .638 & $2 \%$ \\
\hline
\end{tabular}

Sumber: PT.BPR JKT Pariaman Data Diolah

Tahun 2017

$$
\begin{aligned}
N P L= & \frac{\text { Total Kredit Bermasalah }}{\text { Total Kredit }} \times 100 \% \\
& N P L=\frac{R p .721 .979}{R p .33 .667 .703} \times 100 \% \\
& =2 \%
\end{aligned}
$$

Non Perfoming Ratio pada Desember 2017 sebesar 2\%, dengan jumlah kredit sebesar Rp. 33.667 .703 hal tersebut sesuai dengan ketentuan Bank Indonesia bahwa LDR kecil dari 5\% dalam keadaan sehat.

\section{Tahun 2018}

$$
\begin{aligned}
N P L & =\frac{\text { Total Kredit Bermasalah }}{\text { Total Kredit }} \times 100 \% \\
N P L & =\frac{R p \cdot 785.593}{R p .37 .375 .950} \times 100 \% \\
& =2 \%
\end{aligned}
$$

Non Perfoming Ratio pada Desember 2018 dimana nilai NPL pada tahun 2018 2\% dengan jumlah kredit sebesar Rp.37.375.950 hal tersebut sesuai dengan ketentuan Bank Indonesia bahwa LDR kecil dari 5\% dalam keadaan sehat.

\section{Tahun 2019}

$$
\begin{aligned}
N P L & =\frac{\text { Total Kredit Bermasalah }}{\text { Total Kredit }} \times 100 \% \\
N P L & =\frac{R p \cdot 1.168 .651}{R p .40 .136 .638} \times 100 . \% \\
& =2 \%
\end{aligned}
$$

Non Perfoming Ratio pada Desember 2019 kembali mengalami peningkatan sebesar 2\%, dengan jumlah kredit sebesar Rp. 40.136 .638 hal tersebut sesuai dengan ketentuan Bank Indonesia bahwa LDR kecil dari $5 \%$ dalam keadaan sehat. 


\section{SIMPULAN}

Berdasarkan analisis yang telah dilakukan, dapat diketahui bahwa tingkat Loan To Deposit Ratio (LDR) pada PT. BPR JKT Pariaman dapat dilihat pada tahun 2017 sampai 2018 sebesar 89\% dan 93\% dan pada tahun 2019 mengalami penurunan sebesar 91\%. Hal tersebut sesuai dengan ketentuan standar Bank Indonesia bahwa LDR yang berada di bawah $85 \%$ dinyatakan sehat. Hal tersebut dapat disimpulkan bahwa LDR Bank BPR JKT Pariaman sesuai dengan ketentuan standar bank Indonesia bahwa LDR yang berada di bawah $85 \%$ dinyatakan sehat.

Non Perfoming Loan (NPL) pada Bank BPR JKT Pariaman Pada tahun 2017 sampai 2019 sebesar 2\% kecil dari 5\% berarti mengalami bank dalam keadaan sehat sesuai dengan ketentuan Bank Indonesia rasio kecil dari 5\% dalam keadaan baik. terjadinya kredit macet yang setara pada tahun 2017 sampai 2019 adalah permohonan perpanjangan dan penjadwalan kredit usaha nasabah yang terlalu ekspansif dengan mencermati gejala gejala tersebut paling tidak mengurangi atau menekan sekecil mungkin khasus khasus kredit yang masih ada.

\section{Tabel 4}

Evaluasi rata- rata industri

PT. BPR JKT Pariaman

Tahun 2017- 2019

\begin{tabular}{|c|c|c|c|c|c|c|c|}
\hline Rasio & $\begin{array}{l}\text { Rata-rata } \\
\text { Industri }\end{array}$ & $\begin{array}{l}\text { Tahun } \\
2017\end{array}$ & Evaluasi & $\begin{array}{c}\text { Tahun } \\
2018\end{array}$ & Evaluasi & $\begin{array}{l}\text { Tahun } \\
2019\end{array}$ & Evaluasi \\
\hline LDR & $<110 \%$ & $89 \%$ & Sehat & $93 \%$ & Sehat & $91 \%$ & sehat \\
\hline NPL & $<5 \%$ & $2 \%$ & Sehat & $2 \%$ & Sehat & $2 \%$ & sehat \\
\hline
\end{tabular}

Sumber: PT. BPR JKT Pariaman

Berdasarkan analisis perbandingan dapat disimpulkan rasio keuangan PT. Bank perkreditan Rakyat Jorong Kampung Tangah, maka hasil perbandingan dapat diuraikan sebagai berikut:

a. Loan To Deposit Ratio (LDR) PT. Bank perkreditan Rakyat Jorong Kampung Tangah Pariaman pada tahun 2017, 2018, 2019 rata rata di atas minimum secara keseluruhan dan sesuai dengan target yang diberikan Bank Indonesia yaitu sebesar < $110 \%$ artinya bank mampu dalam mengelola likuiditasnya dalam menghimpun dan menyalurkan dananya dalam bentuk kredit kepada masyarakat.

b. Non Performing Loan (NPL) PT. Bank perkreditan Rakyat Jorong Kampung Tangah Pariaman pada tahun 2017, 2018, dan 2019 rata rata di atas minimum sesuai dengan target yang diberikan Bank Indonesia rasio NPL sebesar 5\%, artinya bank mampu mengelola kreditnya dan pengembalian kembali kredit yang diberikan kepada nasabah. 


\section{UCAPAN TERIMA KASIH}

Penulis mengucapkan terimah kasih kepada:

1. Kedua orang tua yang senantiasa memerawat dan mendidik serta mencurahkan kasih dan sayangya pada penulis

2. Direktur AKBP beserta prodi AKBP serta bapak ibu dosen yang telah mendidik dan memberikan ilmu pengetahuan kepada penulis.

3. Pimpinan PT. BPR JKT Pariaman yang telah mengizinkan penulis memperoleh informasi

4. Serta semua pihak yang telah membantu penulis dalam penyelesaian artikel ini.

\section{DAFTAR PUSTAKA}

Agustiningrum, R. (2011). Analisis pengaruh CAR, NPL, dan LDR terhadap profitabilitas pada Perusahaan Perbankan. Riski Agustiningrum, 885-902. https://doi.org/10.1097/MAJ.0b013e31825c6951 [doi]

Amelia, L., \& Marlius, D. (2018). Pengendalian Kredit Dalam Upaya Menciptakan Bank Yang Sehat Pada PT. Bank Pembangunan Daerah Sumatera Barat Cabang Utama Padang. https://doi.org/10.31227/osf.io/kpc64

Arifin, I. Z., \& Marlius, D. (2017). Analisis Kinerja Keuangan PT. Pegadaian Cabang Ulak Karang. https://doi.org/10.31227/osf.io/n2peu

Fernos, J. (2008). Analisis LDR dan PT. Bank Nagari Cabang Pesisir Selatan. 1-10.

Herman, U., \& Widayati, R. (n.d.). Penyelesaian kredit bermasalah pada pt. bank perkreditan rakyat (bpr) nagari kasang. 1-14.

Marlius, D., \& Sukma, J. (2020). Analisis Tingkat Kesehatan Bank Pt. Bank Perkreditan Rakyat Jorong Kampung Tangah Pariaman Cabang Padang. https://doi.org/10.31219/osf.io/dmjy5

Nomor 10 tahun 1998 perubahan atas undang undang nomor 7 tahun 1992. (1998).

Putri, Y. A., \& Marlius, D. (2018). Analisis Tingkat Kesehatan Bank Pada PT. Bank Perkreditan Rakyat (BPR) Jorong Kampuang Tangah Pariaman Cabang Padang. https://doi.org/10.31227/osf.io/r98pv

Rahmayeli, D. S., \& Marlius, D. (2017). Analisis Kinerja Keuangan Pada PT. Bank Perkreditan Rakyat (BPR) Batang Kapas Pesisir Selatan. https://doi.org/10.31227/osf.io/sz5db

Sanjaya, A. R., \& Marlius, D. (2017). Peranan Laporan Keuangan Dalam Kebijaksanaan Pemberian Kredit Kepada Calon Nasabah Pada Pt. Bpr Batang Kapas. Junal Akuntansi Keungan, 12.

Triaryati, N. (2012). Pengaruh Likuiditas (cash Ratio) Dan Loan To Deposit Ratio Terhadap Profitabilitas Aset (ROA) Pada Sektor Perbankan Yang Tercatat Di Bursa Efek Indonesia Periode 2008 - 2012. 1333-1345. 